\title{
SOYBEAN SYMBIOTIC POTENTIAL DEPENDING ON THE STRAIN OF NODULE BACTERIA
}

\author{
Kuuanishbay Aytbayev Djumashovich \\ Ph.D. in Agriculture, Associate professor of the Department Farming, Selection and Seed Breeding of \\ Agricultural Crops, Karakalpakstan Institute of Agriculture and Agrotechnology, Nukus, \\ Karakalpakstan, Uzbekistan
}

Article DOI: https://doi.org/10.36713/epra9209 DOI No: 10.36713/epra9209

\begin{abstract}
SUMMARY
The article is devoted to the analysis of the influence of various strains of nodule bacteria on the formation of the symbiotic potential of soybeans in the conditions of the Republic of Karakalpakstan.

KEYWORDS: Soybeans, nodules, symbiosis, bacteria, strains, nitrogen fixation, potential.
\end{abstract}

\section{INTRODUCTION}

The article is devoted to the analysis of the influence of different strains of nodule bacteria on the formation of symbiotic potential of soybean in the conditions of the Republic of Karakalpakstan.

Under favorable symbiosis conditions, grain legumes fix on average 150 to $180 \mathrm{~kg} / \mathrm{ha}$ of nitrogen from the air and form up to $30 \mathrm{c} / \mathrm{ha}$ of seed. Alfalfa on neutral soils under irrigation during the growing season can use more than $300 \mathrm{~kg} / \mathrm{ha}$ of air nitrogen and provide a hay yield of up to $140 \mathrm{~kg} / \mathrm{ha}$. In order for soybean plants to form a seed yield of $30 \mathrm{~kg} / \mathrm{ha}$, they must assimilate 200 to $300 \mathrm{~kg}$ of nitrogen from the environment. Under good symbiosis conditions they can take $200-220 \mathrm{~kg}$ of nitrogen from the air and the remaining $60-80 \mathrm{~kg}$ from the soil, i.e. at such a high yield relatively little depletion of the soil. Wheat, on the other hand, at a yield of $30 \mathrm{c} / \mathrm{ha}$, taking nitrogen from the soil, depletes it by $117 \mathrm{~kg} / \mathrm{ha}$ [1].

As you know, the Presidential Decree PD5853 of 23 October 2019 adopted the Strategy for the Development of Agriculture in the Republic of Uzbekistan for 2020-2030. Within the framework of this document the modernization of the agrarian sphere with modern approaches has been initiated. In addition, Presidential Decree PD-4512 “On Accelerated Development of Livestock Industries in the Republic of Karakalpakstan" was issued on 7 November 2019. At a video conference, called on the development of the agriculture sectors on 13 November 2019, President Mirziyoyev said: "Unfortunately, there is no effective system in place to ensure an abundance of meat, milk and eggs in our markets, price stability, increased income through crop placement, selection of livestock breeds, creation of a value-added chain, taking proper advantage of the potential of the regions. The need for livestock feed in our country is 120 million tons, but only 47 million tons were produced last year (demand was satisfied by 40 per cent)." Our task is to develop agro-technology of soybean cultivation in conditions of Republic of Karakalpakstan providing balanced high-protein feed for livestock.

\section{THE OBJECT AND METHODOLOGY OF THE RESEARCH}

The objects of our research were strains of nodule bacteria, soybean varieties Selekta 201 and Dustlik. In field experiments 3 strains of nodule bacteria 63371, 63346 and 63341 were studied.

The method of Uzbek Research Institute of Breeding, Seed Production and Agro-Technology of Cotton was used in the experiments. During the research, the "Methodology for conducting field experiments" (2007) and "Methodology for field experiments" by B. Dospekhov (1985) were used.

\section{RESULTS OF SCIENTIFIC RESEARCH}

In our experiments we studied the effect of three strains of nodule bacteria: 63371, 63346 and 63341 on soybean symbiotic potential formation. The experiments were carried out on two varieties: Selekta 201 and Dustlik. The study of the formation of the symbiotic apparatus depending on the activity of the Rhizobium strain showed that in Selekta 201 the nodules were formed faster than in Dustlik 
variety. Thus, in this variety, the appearance of the first nodules was observed in 5 days after sprouting, and in the variety Uzbekskaya-2 in 7 days after sprouting.

The analyses showed that the duration of total and active symbiosis was different in the varieties studied. The duration of symbiosis in variety Dustlik was 10-12 days longer compared to Selekta 201. This is explained by the fact that variety Selekta 201 was early maturing, so the growing season and duration of symbiosis ends faster.

Table 1

Total and active symbiotic potential of soybean varieties depending on the activity of the strain of nodule bacteria, thousand kg.days/ha

\begin{tabular}{|c|c|c|c|c|c|c|c|c|}
\hline \multirow[t]{2}{*}{ Development phase } & \multicolumn{4}{|c|}{ Dustlik } & \multicolumn{4}{|c|}{ Selekta 201} \\
\hline & Control & 63341 & 63346 & 63371 & Control & 63341 & 63346 & 63371 \\
\hline \multicolumn{9}{|c|}{ General } \\
\hline Sprouting - budding & - & 2209 & 2139 & 2338 & - & 2088 & 2108 & 1907 \\
\hline Budding - flowering & - & 2402 & 2433 & 2475 & - & 2357 & 2421 & 2275 \\
\hline Flowering - bean sprouting & - & 1377 & 1337 & 1437 & - & 1488 & 1508 & 1458 \\
\hline Bean filling - ripening & - & 957 & 981 & 1047 & - & 922 & 972 & 907 \\
\hline For the vegetation & - & 6945 & 6890 & 7297 & - & 6855 & 7009 & 6547 \\
\hline \multicolumn{9}{|c|}{ Active } \\
\hline Sprouting - budding & - & 2101 & 2020 & 2209 & - & 1986 & 2012 & 1831 \\
\hline Budding - flowering & - & 2303 & 2314 & 2323 & - & 2211 & 2297 & 2160 \\
\hline Flowering - bean sprouting & - & 1222 & 1258 & 1319 & - & 1422 & 1462 & 1324 \\
\hline Bean filling - ripening & - & 874 & 959 & 963 & - & 873 & 921 & 831 \\
\hline For the vegetation & - & 6500 & 6551 & 6814 & - & 6492 & 6692 & 6146 \\
\hline
\end{tabular}

The results of our experiments show that the studied strains of nodule bacteria have unequal virulence, i.e. specific strains of the same species (Rhizobium japonicum) have unequal ability to penetrate the root of soybean plants. The higher the virulence of the strain, the more bacteria can penetrate the plant root system and form more nodules. Not all of the nodules formed are equally active in fixing air nitrogen. Usually, large pink coloured nodules (depending on the content of light haemoglobin) have the highest nitrogen fixing activity.

Our research also revealed that active strains of nodule bacteria form nodules on the main root, while inactive strains form nodules dispersed along the root system.

Although the duration of symbiosis was similar in both cultivars, the number of common and active nodules as well as their duration were different. For example, strain 63346 was the most virulent and active for the early-season Selekta 201 and strain 63371 for the mid-season cultivar Dustlik. Inoculation of seeds with these strains, ensure the formation of a greater number of active nodules throughout the growing season, while inoculation with other strains was less effective.

The total and active nodule numbers are closely correlated with each other, the proportion of active nodules being $75-80 \%$ of the total.

Our research revealed that saline soils reduce nodule activity with an increase in salt concentration in the soil by $20-25 \%$.
As shown in Table 1, in Dustlik cultivar when seeds were inoculated with specific strain 63371 the active symbiotic potential was 6-8\% higher compared to inoculation with other strains. In cultivar Selekta 201 the active symbiotic potential was $8-10 \%$ higher when seeds were inoculated with strain 63346 compared to the other experimental variants.

\section{CONCLUSION}

Thus, under our conditions on soils salinized to different degrees, the most specific, virulent, active and complementary strains were identified for early maturing Select 201 and medium maturing cultivar Dustlik, respectively, by the size and activity of symbiotic apparatus: 63346 и 63371.

\section{LIST OF REFERENCES}

1. Vavilov P.P., Posipanov G.S. Legumes and the problem of plant protein: Monograph / - M., Rosselkhozizdat, 1983. - P. 27-28.

2. "Methodology of field studies" - T., UZNIIH, 2007. P. 147.

3. Dospekhov B.A. Methodology of field experience, M., Kolos, 1985. 